\title{
Pengaruh Rentabilitas, Leverage, Dan Saham Bonus Pada Nilai Perusahaan Di Bursa Efek Indonesia
}

\author{
Ni Wayan Yusy Marthadiani ${ }^{1}$ \\ Ida Bagus Putra Astika ${ }^{2}$ \\ ${ }^{1,2}$ Fakultas Ekonomi dan Bisnis Universitas Udayana (Unud), Bali, Indonesia \\ e-mail: yusymarthadiani@ymail.com
}

\begin{abstract}
ABSTRAK
Dimata investor nilai perusahaan merupakan pencerminan prospek perusahaan. Salah satu bentuk dari nilai perusahaan adalah perubahan harga pasar saham perusahaan. Penelitian ini bertujuan untuk mendapatkan bukti empiris pengaruh rentabilitas, leverage, dan saham bonus pada nilai perusahaan. Penelitian ini dilakukan pada seluruh sektor perusahaan yang listing di Bursa Efek Indonesia periode 2000-2016. Pemilihan sampel menggunakan teknik purposive sampling dengan metode non probability sampling. Banyaknya populasi yang digunakan sebanyak 37 perusahaan dan jumlah sampel yang diperoleh yaitu 35 observasian. Data dalam penelitian ini dianalisis menggunakan metode regresi linier berganda. Berdasarkan hasil penelitian yang dilakukan dapat diketahui bahwa rentabilitas berpengaruh negatif pada nilai perusahaan. Leverage memberikan pengaruh positif pada nilai perusahaan, sedangkan saham bonus tidak berpengaruh pada nilai perusahaan.
\end{abstract}

Kata Kunci: Rentabilitas, Leverage, Saham Bonus, dan Nilai Perusahaan.

\begin{abstract}
Firm value in investor's perspective is the reflection of company's prospects. One form of firm value is the change in the market price of a company's stock. This research aims to obtain empirical evidence of the effect of profitability, leverage, and bonus shares on firm value. This research was conducted on companies in all sectors listed on the Indonesia Stock Exchange for the period 2000-2016. The sample selection used purposive sampling technique with non probability sampling method. The population of this research consisted of 37 companies and the number of samples obtained 35 observations. The data in this study was analyzed using the multiple linear regression methods. Based on the results of the research, it can be concluded that profitability has a negative effect on firm value. Leverage has a positive effect on firm value, and bonus shares do not affect firm value. Keywords: Profitability, Leverage, Bonus Shares, and Firm Value.
\end{abstract}

\section{PENDAHULUAN}

Pesatnya perkembangan pasar modal saat ini mendorong perusahaan-perusahaan go public untuk berlomba dalam mencapai tujuan utama perusahaannya, dimana tidak hanya ingin memaksimumkan laba saja tetapi juga memaksimumkan nilai perusahaan. Nilai perusahaan yang maksimum akan meningkatkan nilai pemegang 
saham yang ditandai dengan adanya peningkatan pengembalian investasi yang tinggi pada shareholders (Suharli, 2006). Kesejahteraan pemegang saham merupakan tujuan dari perusahaan, hal ini terlihat dari nilai saham perusahaan (Brigham \& Daves, 2000). Jika harga saham semakin tinggi, maka semakin tinggi pula tingkat pengembalian kepada investor sehingga berimplikasi pada semakin tingginya nilai perusahaan terkait tujuan dari perusahaan itu sendiri (Gultom, 2008 dalam Mahfudatin dan Maslichah, 2018). Nilai perusahaan pada dasarnya diukur dari beberapa aspek salah satunya adalah harga pasar saham yang mencerminkan penilaian investor atas keseluruhan ekuitas yang dimiliki (Larasdiputra dkk., 2017).

Salah satu indikator yang dapat digunakan untuk mengukur nilai perusahaan dalam penelitian ini adalah Tobin's $Q$. Tobin's $Q$ dianggap dapat memberikan informasi yang paling baik dengan menggabungkan semua unsur hutang, modal saham, dan aset perusahaan. Harga saham yang digunakan dalam perhitungan Tobin's $Q$ adalah harga saat penutupan (closing price) sehingga memungkinkan terjadinya fluktuasi harga pasar saham yang kemudian akan berdampak pada nilai perusahaan itu sendiri. Fluktuasi nilai perusahaan pada seluruh sektor yang mengeluarkan kebijakan saham bonus periode 2000-2014 ditunjukkan pada Gambar 1 berikut. 


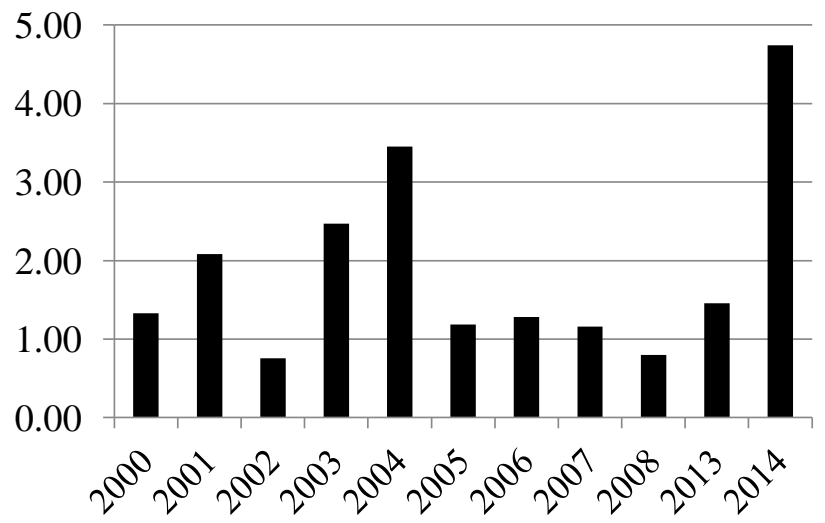

- Nilai Perusahaan

\section{Gambar 1. Grafik Nilai Perusahaan Seluruh Sektor Perusahaan di BEI} Sumber: Data diolah, 2018

Data dalam Gambar 1 merupakan hasil rekapitulasi perhitungan nilai perusahaan yang mengeluarkan saham bonus periode 2000-2014 dengan proksi Tobin's $Q$, dimana hasil rekapitulasi diperoleh dari data sampel yang digunakan dalam penelitian ini. Berdasarkan Gambar 1 menunjukkan bahwa nilai perusahaan pada tahun 2000 berada pada nilai 1,33 persen, lalu mengalami peningkatan pada tahun 2001 sebesar 2,08 persen, namun mengalami penurunan pada tahun 2002 sebesar 0,76 persen. Pada tahun 2003, nilai perusahaan kembali mengalami peningkatan sebesar 2,47 persen dan tetap meningkat pada tahun 2004 sebesar 3,45 persen, lalu mengalami penurunan pada tahun 2005 yang cukup signifikan sebesar 1,19 persen kemudian mengalami peningkatan kembali sebesar 1,28 persen pada tahun 2006. Nilai perusahaan kembali mengalami penurunan pada tahun 2007 dan 2008 masing-masing sebesar 1,16 persen dan 0,80 persen, dimana kemudian nilai perusahaan perlahan mengalami peningkatan di tahun 2013 sebesar 1,46 persen dan meningkat drastis sebesar 4,74 persen pada tahun 2014. Tingkat nilai perusahaan terendah dialami pada tahun 2002 dan tertinggi pada 
tahun 2014. Hal tersebut menunjukkan bahwa nilai perusahaan pada seluruh sektor terhadap perusahaan yang melakukan kebijakan saham bonus mengalami tingkat fluktuasi yang cukup signifikan.

Nilai perusahaan dijadikan fokus utama dalam pengambilan keputusan oleh investor untuk berinvestasi pada suatu perusahaan atau tidak. Untuk dapat menarik minat investor, pemegang saham mempercayakan pengelolaan kepada pihak lain dalam hal ini manajemen dalam rangka meningkatkan nilai perusahaan. Memaksimumkan nilai perusahaan dalam jangka panjang dapat berarti manajer dituntut untuk membuat keputusan yang memperhitungkan kepentingan semua stakeholders, sehingga kinerja manajer akan dinilai bagus atau tidaknya melalui kemampuannya untuk mencapai tujuan perusahaan yang telah ditetapkan. Dilihat dari teori keagenan, strategi yang dapat dilakukan manajer sebagai pengelola perusahaan dalam menjalankan proses untuk mencapai tujuan perusahaan diantaranya menjadikan laporan keuangan dan kinerja keuangan perusahaan terlihat menarik serta pengambilan kebijakan yang tepat terhadap situasi yang menyangkut saham perusahaan, sehingga dapat menarik minat investor untuk berinvestasi. Menurut Analisa (2011), faktor-faktor yang dapat memengaruhi nilai perusahaan diantaranya berupa ukuran perusahaan, pertumbuhan, keunikan, risiko keuangan, profitabilitas, pembayaran pajak, pembayaran dividen, kebijakan perusahaan dan lain sebagainya.

Kebijakan perusahaan berupa aksi korporasi merupakan salah satu faktor yang dapat memengaruhi nilai perusahaan. Jenis aksi korporasi yang dapat dilakukan manajer dalam menarik perhatian investor adalah dengan mengeluarkan 
kebijakan saham bonus. Saham bonus (bonus share) dapat memengaruhi jumlah dan harga saham yang beredar dan porsi saham dibagikan secara proporsional sesuai jumlah saham yang dimiliki investor (Samsul, 2006:191). Kebijakan saham bonus dilakukan oleh perusahaan ketika investor menilai kinerja perusahaan tidak sesuai harapan, sehingga kebijakan ini bertujuan agar likuiditas perusahaan meningkat (Shirur, 2008).

Saham bonus dapat menjadi sinyal manajemen kepada investor di pasar saham, dimana kondisi ini sejalan dengan teori sinyal yang menjelaskan bahwa perusahaan melakukan kebijakan saham bonus jika manajer yakin dengan prospek perusahaan. Tindakan untuk mengeluarkan kebijakan saham bonus bagi sejumlah besar perusahaan yang listing di pasar modal adalah wajar dilakukan dalam usaha meningkatkan nilai perusahaan sehingga dapat menarik investor untuk melakukan trading. Hal tersebut sejalan dengan penelitian Lakonishok dan Lev (1987) serta Barnes dan Ma (2002) yang mengatakan bahwa saham bonus memberikan respon positif kepada pasar (investor) karena harga saham akan menjadi lebih kecil sehingga akan lebih meningkatkan kemampuan pasar terhadap saham tersebut yang akan berimplikasi pada peningkatan nilai perusahaan. Penelitian oleh (Larasdiputra dkk., 2017) juga mengatakan bahwa saham bonus berpengaruh positif terhadap nilai perusahaan, sedangkan penelitian yang dilakukan oleh Ardiansyah (2013), Dewi dan Sukartha (2015) mengatakan bahwa kebijakan saham bonus merupakan bad news bagi investor serta Mahfudatin dan Maslichah (2018) membuktikan bahwa saham bonus tidak berpengaruh terhadap nilai perusahaan. 
Salah satu bentuk kinerja keuangan yang dapat memengaruhi nilai perusahaan yaitu profitabilitas atau yang dapat disebut dengan rentabilitas. Rentabilitas memiliki arti penting dalam usaha untuk mempertahankan kelangsungan hidup perusahan dalam jangka panjang karena rentabilitas menunjukkan apakah perusahaan memiliki prospek yang baik. Rentabilitas dapat diukur dengan menggunakan rasio-rasio keuangan atau tingkat perubahan laba. Perusahaan dapat dikatakan berhasil atau memiliki kinerja baik apabila tingkat pengembalian atas investasi perusahaan menunjukkan peningkatan dari periode sebelumnya atau memperoleh laba yang besar, begitupula sebaliknya (Prasetyorini, 2013). Penelitian oleh Larasdiputra dkk., (2017), mengatakan bahwa rentabilitas positif menunjukan bahwa total aktiva yang dipergunakan untuk operasi perusahaan mampu memberikan laba bagi perusahaan, sehingga diperkirakan peluang untuk melakukan pembagian dividen semakin besar dan peluang untuk melakukan pembagian dividen saham semakin kecil.

Hasil tersebut dapat berimplikasi pada menurunnya likuiditas perusahaan dikarenakan perolehan laba yang tinggi biasanya digunakan perusahaan sebagai laba cadangan yang bisa memungkinkan diadakannya pembagian dividen tunai, namun jika hampir seluruh laba digunakan untuk pembagian dividen maka likuiditas perusahaan dapat menurun karena jumlah kas yang tersisa adalah sedikit. Likuiditas perusahaan yang relatif tinggi menunjukkan gambaran bahwa pengelolaan aset dilakukan dengan sangat konservatif dan manajemen menekankan pada pola keamanan keuangan perusahaan, namun model pengelolaan tersebut mengabaikan rentabilitas. Hal tersebut dikarenakan dalam 
pos aktiva terdapat piutang dan aset tak bergerak yang bernilai tinggi sehingga mengakibatkan kas perusahaan menjadi rendah yang akan berdampak pada menurunnya rentabilitas atau laba perusahaan. Penelitian oleh Khumairoh dkk., (2016) serta Hermawan dan Maf'ulah (2014) mengatakan bahwa profitabilitas tidak berpengaruh pada nilai perusahaan. Penelitian oleh Triagustina dkk., (2015) dan Munawaroh (2013) mengatakan bahwa rentabilitas berpengaruh negatif terhadap nilai perusahaan, sedangkan penelitian menurut Menawati dan Astika (2017), Chen dan Chen (2011), Gill dan Obradovich (2012) serta Hasibuan dkk., (2016) mengatakan bahwa rentabilitas berpengaruh positif terhadap nilai perusahaan.

Faktor lain yang dapat berpengaruh pada nilai perusahaan yaitu leverage. Menurut Herry dan Hamin (2005) serta Modigliani dan Miller (1963) dalam Miftah (2008), leverage menyebabkan peningkatan nilai perusahaan (value enchancing). Rasio leverage juga menunjukkan risiko yang dihadapi perusahaan, yaitu semakin besar leverage menunjukkan semakin besar pula resiko investasinya (Wiagustini, 2014:85). Hal ini dikarenakan semakin tinggi rasio menunjukkan semakin besar dana yang disediakan oleh kreditur sehingga investor perlu berhati-hati dalam melakukan keputusan investasi. Penelitian ini didukung oleh Adelegan (2006), Dimitrov dan Jain (2008), Siahaan (2013), Myers (1977), Lyandres \& Zhdanov (2010) menyatakan bahwa leverage berpengaruh negatif signifikan terhadap nilai perusahaan, sedangkan penelitian Tarihoran (2016), Cheng dan Tzeng (2011) serta Pratama dan Wiksuana (2016), menyebutkan leverage berpengaruh positif signifikan terhadap nilai perusahaan. 
Berdasarkan kondisi, teori, dan hasil penelitian terdahulu yang memberikan hasil yang tidak konsisten, maka dari itu penulis termotivasi untuk memperoleh bukti empiris mengenai pengaruh rentabilitas, leverage dan saham bonus pada nilai perusahaan di Bursa Efek Indonesia. Motivasi kedua, penelitian tentang rentabilitas dan leverage sudah sering dilakukan untuk meneliti pengaruhnya pada nilai perusahaan, sedangkan jumlah penelitian mengenai corporate action jenis saham bonus masih relatif jarang dilakukan di Indonesia. Ketiga, penelitian ini memiliki keunikan karena kebijakan saham bonus dalam penerapannya di perusahaan ternyata menuai kontradiksi antara teori dan praktiknya. Pasalnya kebijakan ini terbilang unik karena kebijakan ini seolah-olah memberikan keuntungan kepada pemegang saham, namun kenyataannya yang terjadi hanyalah perpindahan pos di dalam neraca dan emiten tidak memperoleh aset atau penambahan kekayaan. Meskipun begitu, dalam praktiknya kebijakan ini juga masih dilakukan oleh beberapa perusahaan.

Berdasarkan kajian pustaka dan penelitian terdahulu, penelitian ini terdiri atas grand theory dan supporting theory yang digunakan untuk menguji apakah variabel independen berpengaruh pada variabel dependen. Dalam hal ini grand theory ditunjukkan oleh teori keagenan dan supporting theory ditunjukkan oleh teori sinyal. Teori keagenan yang merupakan hubungan atau kontrak antara pemilik perusahaan (principle) dan manajemen (agent) ternyata berpotensi konflik, karena adanya perbedaan kepentingan dan manajemen selalu memanfaatkan kesempatan yang ada untuk berperilaku oportunistik sehingga munculah asimetri informasi. Teori keagenan adalah salah satu pendekatan yang 
dapat digunakan dalam menjelaskan rentabilitas, leverage, dan saham bonus karena agent lebih memahami semua hal yang terjadi di perusahaan. Agent akan mengambil keputusan untuk melakukan kebijakan atau cara apapun agar dapat mencapai tujuan perusahaan sehingga kinerja perusahaan akan terlihat menjadi baik dimata investor yang akan berimplikasi pada meningkatnya nilai perusahaan.

Teori sinyal berasumsi bahwa pihak manajemen perusahaan mempunyai akses informasi yang lengkap dan benar tentang nilai dari perusahaan yang tidak dimiliki oleh investor luar. Cara manajemen perusahaan untuk mengurangi asimetri informasi adalah dengan memberikan sinyal kepada investor dengan harapan investor akan bereaksi terhadap kebijakan yang dilakukan perusahaan tersebut. Dalam situasi tersebut terdapat beberapa tindakan yang diambil oleh manajer perusahaan untuk meningkatkan nilai perusahaan, yaitu dengan mengendalikan tingkat rentabilitas, menggunakan hutang sebagai sumber pendanaan, dan melakukan kebijakan saham bonus. Kedua teori ini merupakan pendekatan yang dapat menjelaskan rentabilitas, leverage, dan kebijakan saham bonus apakah memiliki pengaruh atau tidaknya pada nilai perusahaan yang tercermin melalui nilai pasar saham pada perusahaan tersebut. Berdasarkan penjelasan di atas, maka kerangka konseptual dalam penelitian ini dapat digambarkan sebagai berikut: 


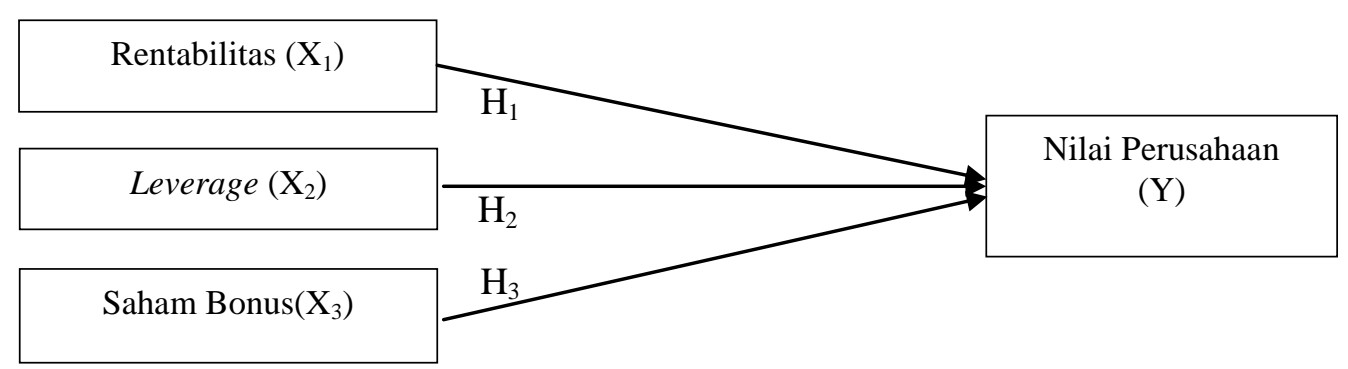

Sumber: Data diolah, 2018

\section{Gambar 2. Kerangka Konseptual}

Berdasarkan pada tujuan penelitian dan kajian-kajian teori yang relevan ataupun hasil dari penelitian sebelumnya, maka hipotesis dalam penelitian ini adalah sebagai berikut:

$\mathrm{H}_{1}$ : Rentabilitas berpengaruh positif pada nilai perusahaan.

$\mathrm{H}_{2}$ : Leverage berpengaruh positif pada nilai perusahaan.

$\mathrm{H}_{3}$ : Saham bonus berpengaruh positif pada nilai perusahaan.

\section{METODE PENELITIAN}

Penelitian ini menggunakan pendekatan kuantitatif dan berbentuk asosiatif untuk mengetahui hubungan atau pengaruh satu atau lebih variabel independen dengan satu variabel dependen (Sugiyono, 2017: 37) yaitu untuk mengetahui pengaruh rentabilitas, leverage, dan saham bonus pada nilai perusahaan di Bursa Efek Indonesia.

Penelitian ini berlokasi di Bursa Efek Indonesia pada seluruh perusahaan periode 2000-2016 dengan mengakses data melalui situs www.idx.co.id dan Indonesian Capital Market Directory (ICMD). Obyek penelitian dalam penelitian ini adalah nilai perusahaan seluruh sektor usaha yang terdaftar di BEI periode 
2000-2016 yang dipengaruhi oleh beberapa faktor yakni rentabilitas, leverage, dan saham bonus.

Penelitian ini menggunakan dua buah variabel, yaitu variabel terikat (dependen) dan variabel bebas (independen). Variabel terikat dalam penelitian ini adalah nilai perusahaan yang diproksikan dengan Tobin's $Q$. Rumus nilai perusahaan dengan proksi Tobin's $Q$ (Chung dan Pruitt, 1994):

Tobin's $Q=\frac{\text { Market Value of Equity+Total Debt }}{\text { Total Assets }}$

Variabel bebas dalam penelitian ini adalah rentabilitas, leverage, dan saham bonus. Rentabilitas merupakan suatu alat dalam mengukur penghasilan bersih yang diproksikan dengan perubahan laba dapat dihitung dengan rumus (Agustina dan Silvia, 2012):

Perubahan Laba $=\frac{\text { laba t0-laba t-1 }}{\text { laba } \mathrm{t}-1}$

Keterangan:

$\mathrm{t}_{0} \quad$ : Laba tahun sekarang

$\mathrm{t}^{-1} \quad$ : Laba tahun sebelumnya

Leverage adalah kemampuan perusahaan untuk memenuhi kewajiban finansial jangka panjang maupun jangka pendek. Rasio leverage memperlihatkan proporsi total utang jangka panjang perusahaan terhadap total aset yang dimiliki oleh perusahaan. Leverage dapat dihitung dengan rumus (Dirgantara dan Lubis, 2013):

Perubahan Tingkat Utang $=\frac{\text { total utang } \mathrm{t} 0 \text {-total } \mathrm{utang} \mathrm{t}-1}{\text { total utang } \mathrm{t}-1}$.

Keterangan:

$\mathrm{t}_{0} \quad$ : Total utang tahun sekarang

$\mathrm{t}_{-1} \quad$ : Total utang tahun sebelumnya 
Saham bonus merupakan salah satu aksi korporasi yang dapat mempengaruhi harga dan jumlah saham yang beredar, dimana saham bonus memasukkan jumlah saham bonus yang dibagikan dan jumlah saham yang beredar. Adanya peningkatan jumlah saham yang beredar menyebabkan likuiditas saham perusahaan akan meningkat sehingga dapat menarik investor untuk berinvestasi di perusahaan sehingga dapat meningkatkan nilai dari perusahaan. Hasil pembagian saham bonus kemudian dapat dirumuskan sebagai berikut (Samsul, 2006:122):

Saham bonus $=\frac{\text { Jumlah saham bonus }}{\text { Jumlah saham yang beredar }}$

Populasi yang digunakan pada penelitian ini adalah seluruh perusahaan go public yang terdaftar di Bursa Efek Indonesia periode 2000-2016 sebanyak 37 perusahaan. Metode penentuan sampel yang digunakan pada penelitian ini adalah metode non-probability sampling dengan teknik purposive sampling yaitu penentuan sampel dengan menggunakan kriteria bahwa perusahaan listing dan menerbitkan saham bonus serta laporan keuangan tahunan (annual report) menggunakan mata uang rupiah dalam pelaporannya secara lengkap selama periode amatan tahun 2000-2016 di Bursa Efek Indonesia.

Teknik analisis data yang digunakan dalam penelitian ini adalah analisis regresi linier berganda (multiple). Teknik analisis regresi linear berganda digunakan untuk mengetahui keadaan suatu variabel terikat apabila terjadi perubahan terhadap dua variabel atau lebih variabel bebas. Penggunaan analisis ini memiliki syarat yaitu lolos dari uji asumsi klasik dan uji kelayakan model (goodness of fit). Analisis ini bertujuan untuk mencari pengaruh Rentabilitas $\left(\mathrm{X}_{1}\right)$, 
Leverage $\left(\mathrm{X}_{2}\right)$, Saham Bonus $\left(\mathrm{X}_{3}\right)$ pada Nilai Perusahaan $(\mathrm{Y})$. Secara sistematis persamaan regresi yang diperoleh yakni:

$\mathrm{Y}=\alpha+\beta_{1} \cdot \mathrm{X}_{1}+\beta_{2} \cdot \mathrm{X}_{2}+\beta_{3} \cdot \mathrm{X}_{3}+e$

Keterangan:

$\mathrm{Y}=$ Variabel dependen nilai perusahaan

$\mathrm{X}_{1,2,3}=$ Variabel independen rentabilitas, leverage, saham bonus

$\alpha \quad=$ Konstanta

$\beta_{1,2,3}=$ Koefisien regresi (nilai peningkatan ataupun penurunan)

\section{HASIL DAN PEMBAHASAN}

Statistik deskriptif berhubungan dengan pengumpulan dan peringkat data yang menggambarkan karakteristik sampel yang digunakan dalam penelitian ini. Analisis ini berguna untuk menjelaskan karateristik sampel terutama mencakup nilai rata-rata (mean), nilai ekstrim yaitu nilai minimum dan nilai maksimum, serta standar deviasi dari masing-masing variabel. Hasil dari statistik deskriptif tersebut dapat dilihat pada Tabel 1 .

Tabel 1.

Hasil Uji Statistik Deskriptif

\begin{tabular}{lccccc}
\hline & $N$ & Minimum & Maximum & Mean & Std. Deviation \\
\hline TBQ & 35 & 0,51 & 5,50 & 1,3714 & 0,97447 \\
DEL_LABA & 35 & $-13,61$ & 11,01 & $-0,0389$ & 3,16272 \\
DEL_HUT & 35 & $-0,50$ & 7,65 & 0,4654 & 1,30764 \\
S_BONUS & 35 & 0,00 & 0,73 & 0,3370 & 0,22237 \\
Valid N (listwise) & 35 & & & & \\
\hline
\end{tabular}

Sumber: Data diolah, 2018

Berdasarkan Tabel 1 diatas, dapat diketahui bahwa jumlah observasi (N) sebanyak 35. Nilai terendah dari data ditunjukkan oleh skor minimum, sedangkan nilai tertinggi dari data ditunjukkan oleh skor maksimum dalam tabel. Mean digunakan untuk mengukur nilai rata-rata dari data, dan standar deviasi 
menunjukkan simpangan baku. Nilai terendah (minimum) variabel rentabilitas yang diproksikan dengan delta laba adalah $-13,61$, sedangkan nilai tertinggi (maksimum) sebesar 11,01. Nilai rata-rata pada variabel rentabilitas adalah sebesar -0,0389. Deviasi standar variabel rentabilitas sebesar 3,16272 hal ini menunjukan bahwa standar penyimpangan data terhadap nilai rata-ratanya sebesar 3,16272 .

Nilai terendah (minimum) variabel leverage adalah $-0,50$, sedangkan nilai tertinggi (maksimum) sebesar 7,65. Nilai rata-rata pada variabel leverage sebesar 0,4654. Deviasi standar variabel leverage sebesar 1,30764 hal ini menunjukan bahwa standar penyimpangan data terhadap nilai rata-ratanya sebesar 1,30764. Nilai terendah (minimum) variabel saham bonus adalah 0,00 , sedangkan nilai tertinggi (maksimum) sebesar 0,73 . Nilai rata-rata pada variabel saham bonus sebesar 0,3370. Deviasi standar variabel saham bonus sebesar 0,22237 hal ini menunjukan bahwa standar penyimpangan data terhadap nilai rata-ratanya sebesar 0,22237 .

Analisis regresi sangat memerlukan bagian asumsi agar model dapat digunakan sebagai alat prediksi baik. Oleh karena itu dalam penelitian ini dilakukan uji asumsi klasik yang meliputi uji normalitas, uji multikolinearitas, dan uji heteroskedastisitas. Oleh karena seluruh uji asumsi klasik dalam penelitian ini sudah memenuh syarat, maka uji regresi linier berganda layak di analisis lebih lanjut dengan melihat uji kelayakan model, uji koefisien determinasi dan uji hipotesis masing-masing variabel. Uji regresi linier berganda dipergunakan apabila ingin mengetahui hubungan antar dua atau lebih variabel independen ke 
variabel dependen dalam bentuk linier. Hasil uji regresi linier berganda dapat dilihat pada Tabel 2 .

Tabel 2.

Hasil Uji Regresi Linier Berganda

\begin{tabular}{|c|c|c|c|c|c|c|}
\hline \multirow[b]{2}{*}{ Model } & & \multicolumn{2}{|c|}{ Unstandardized Coefficients } & \multirow{2}{*}{$\begin{array}{c}\text { Standardized } \\
\text { Coefficients } \\
\text { Beta }\end{array}$} & \multirow[t]{2}{*}{$T$} & \multirow[t]{2}{*}{ Sig. } \\
\hline & & $B$ & Std. Error & & & \\
\hline 1 & (Constant) & 1,254 & 0,254 & & 4,946 & 0,000 \\
\hline & DEL_LABA & $-0,187$ & 0,042 & $-0,606$ & $-4,430$ & 0,000 \\
\hline & DEL_HUT & 0,270 & 0,102 & 0,363 & 2,656 & 0,012 \\
\hline & S_BONUS & $-0,047$ & 0,605 & $-0,011$ & $-0,077$ & 0,939 \\
\hline & $\begin{array}{l}\text { Adjusted } R \\
\text { Square }\left(R^{2}\right)\end{array}$ & 0,400 & & & & \\
\hline & F Hitung & 8,558 & & & & \\
\hline & Sig. F & $0,000^{\mathrm{b}}$ & & & & \\
\hline
\end{tabular}

Berdasarkan hasil analisis uji regresi linier berganda yang ditunjukkan pada

Tabel 2, maka disusun persamaan regresi sebagai berikut:

$$
\mathrm{Y}=1,254-0,187 \mathrm{X}_{1}+0,270 \mathrm{X}_{2}-0,047 \mathrm{X}_{3}
$$

Berdasarkan persamaan tersebut terlihat bahwa terdapat pengaruh positif variabel leverage $\left(\mathrm{X}_{2}\right)$ pada nilai perusahaan $(\mathrm{Y})$. Sedangkan variabel rentabilitas $\left(\mathrm{X}_{1}\right)$ memiliki pengaruh negatif pada nilai perusahaan $(\mathrm{Y})$ dan variabel saham bonus $\left(\mathrm{X}_{3}\right)$ tidak memiliki pengaruh pada nilai perusahaan $(\mathrm{Y})$.

Berdasarkan persamaan diatas, dapat dijelaskan bahwa nilai konstanta 1,254 yang berarti bila variabel rentabilitas, leverage dan saham bonus sama dengan nol, maka variabel nilai perusahaan akan bernilai sebesar 1,254. Nilai koefisien regresi rentabilitas sebesar $-0,187$ menunjukan bahwa bila rentabilitas naik satu satuan, maka nilai perusahaan akan mengalami penurunan sebesar 0,187 satuan dengan asumsi variabel lainnya konstan. Nilai koefisien regresi leverage sebesar 0,270 menunjukan bahwa bila leverage naik satu satuan, maka nilai perusahaan akan 
mengalami peningkatan sebesar 0,270 satuan dengan asumsi variabel lainnya konstan. Nilai koefisien regresi saham bonus sebesar -0,047 menunjukan bahwa bila saham bonus naik satu satuan, maka nilai perusahaan akan mengalami penurunan sebesar 0,047 satuan dengan asumsi variabel lainnya konstan.

Uji kelayakan model bertujuan untuk mengetahui apakah model regresi dalam penelitian ini layak digunakan untuk uji hipotesis. Bila nilai sig. dari $\mathrm{F} \leq \alpha$ sebesar 5\%, maka memenuhi syarat untuk uji kelayakan model. Berdasarkan Tabel 2 dapat disimpulkan bahwa nilai signifikansi yang diperoleh sebesar 0,000, dimana hasil tersebut lebih kecil dari $\alpha=0,05$. Sehingga dapat dikatakan bahwa model regresi ini sudah layak untuk digunakan.

Koefisien determinasi $\left(\mathrm{R}^{2}\right)$ digunakan untuk mengukur kemampuan variabel bebas (independen) menjelaskan variasi perubahan variabel terikat (dependen). Semakin tinggi nilai koefisien determinasi $\left(\mathrm{R}^{2}\right)$ maka semakin tinggi kemampuan variabel independen menjelaskan variasi variabel dependennya. Berdasarkan Tabel 2 dapat diketahui bahwa nilai adjusted $\mathrm{R}^{2}$ adalah 0,400 atau sebesar 40 persen yang berarti bahwa variasi perubahan yang terjadi pada nilai perusahaan dapat dijelaskan oleh variabel rentabilitas, leverage, dan saham bonus sebesar 40 persen sedangkan 60 persen sisanya dijelaskan oleh faktor lain diluar model penelitian ini.

Hipotesis pertama $\left(\mathrm{H}_{1}\right)$ dalam penelitian ini menyatakan bahwa rentabilitas berpengaruh positif pada nilai perusahaan. Berdasarkan hasil uji hipotesis yang ditunjukkan pada Tabel 2, menunjukkan bahwa koefisien regresi sebesar -0,187 dengan tingkat signifikansi sebesar 0,000 lebih kecil daripada 0,05. Hal tersebut 
berarti hipotesis ditolak, sehingga dapat disimpulkan bahwa rentabilitas berpengaruh negatif pada nilai perusahaan. Hasil penelitian ini mendukung teori sinyal dimana hipotesis pertama memberikan sinyal buruk (bad news) bagi investor. Tingkat perubahan laba dalam penelitian ini sebagai proksi dari rentabilitas berpengaruh negatif pada nilai perusahaan.

Rentabilitas dapat memberikan dua pengaruh yang berbeda terhadap nilai perusahaan. Hal tersebut dapat dilihat dari peningkatan atau penurunan tingkat suku bunga yang tentunya akan memberikan dampak positif atau negatif terhadap nilai perusahaan. Perusahaan yang meningkatkan tingkat suku bunga dapat meningkatkan rentabilitas perusahaan, namun juga dapat berdampak terhadap menurunnya tingkat likuiditas perusahaan diikuti oleh menurunnya minat investor untuk berinvestasi pada saham perusahaan yang bersangkutan sehingga dapat menurunkan nilai perusahaan tersebut. Meskipun rentabilitas perusahaan tinggi, namun jika terdapat piutang yang tidak tertagih atau macet maka kecenderungan investor akan lebih mengamankan uangnya di bank dengan return yang lebih tinggi dibandingkan menginvestasikannya dalam perusahaan, sehingga nilai perusahaan akan menurun. Lestari (2016) menyebutkan bahwa profitabilitas memiliki pengaruh negatif signifikan terhadap nilai perusahaan, yang artinya nilai profitabilitas yang meningkat tidak selamanya akan membuat nilai perusahaan juga meningkat karena hal tersebut juga dipengaruhi oleh faktor-faktor lain. Penelitian ini didukung oleh penelitian Sally (2015), Wulandari dan Wiksuana (2017), Triagustina dkk., (2015) dan Munawaroh (2013) yang menemukan bahwa profitabilitas berpengaruh negatif terhadap nilai perusahaan. Penelitian oleh 
Carningsih (2009) dengan menggunakan sampel perusahaan property \& real estate juga menemukan bahwa profitabilitas berpengaruh negatif pada nilai perusahaan.

Hipotesis kedua $\left(\mathrm{H}_{2}\right)$ dalam penelitian ini menyatakan bahwa leverage berpengaruh positif pada nilai perusahaan. Berdasarkan hasil uji hipotesis yang ditunjukkan pada Tabel 2, menunjukkan bahwa koefisien regresi sebesar 0,270 dengan tingkat signifikansi sebesar 0,012 lebih kecil daripada 0,05. Hal tersebut berarti hipotesis diterima, sehingga dapat disimpulkan bahwa leverage berpengaruh positif signifikan pada nilai perusahaan. Hasil penelitian ini mendukung teori keagenan dan teori sinyal yang menyatakan bahwa kebijakan utang dapat dilakukan oleh manajer perusahaan sebagai sinyal kepada investor bahwa perusahaan tesebut lebih dipercaya karena perusahaan yang meningkatkan utang bisa dipandang sebagai perusahaan yang yakin dengan prospek perusahaan di masa mendatang (Titman dan Wessels, 1988). Peningkatan persentase perubahan tingkat utang sebagai proksi dari leverage dapat memberikan sinyal yang baik (good news) karena mencerminkan kemampuan perusahaan terutama manajemen sebagai pengelola untuk meningkatkan nilai perusahaan.

Semakin tinggi persentase perubahan tingkat utang maka semakin tinggi pula nilai perusahaan. Tingginya rasio leverage menunjukkan perusahaanperusahaan lebih banyak menggunakan pendanaan melalui utang. Hal ini dikarenakan penggunaan dana utang dapat digunakan untuk melakukan ekspansi perusahaan serta dapat memberikan prospek usaha yang baik dikedepannya sehingga dapat meningkatkan nilai perusahaan. Perusahaan dengan leverage 
tinggi dalam penelitian ini dinilai sebagai perusahaan yang memiliki kemampuan mengendalikan risiko keuangan dengan baik. Dengan kata lain, semakin tinggi proporsi utang maka akan semakin tinggi nilai perusahaan dikarenakan pengelolaan yang baik terhadap utang tersebut. Penelitian ini didukung oleh penelitian Titman dan Wessels (1988), Herry dan Hamin (2005), Pratama dan Wiksuana (2016), Dewi dan Wirajaya (2013) dan Analisa (2011) yang menemukan bahwa leverage berpengaruh positif signifikan pada nilai perusahaan.

Hipotesis ketiga $\left(\mathrm{H}_{3}\right)$ dalam penelitian ini menyatakan bahwa saham bonus tidak berpengaruh pada nilai perusahaan. Berdasarkan hasil uji hipotesis yang ditunjukkan pada Tabel 2, menunjukkan bahwa koefisien regresi sebesar -0,047 dengan tingkat signifikansi sebesar 0,939 lebih besar daripada 0,05. Hal tersebut berarti hipotesis ditolak, sehingga dapat disimpulkan bahwa saham bonus tidak berpengaruh pada nilai perusahaan. Semakin tinggi atau rendah intensitas pengambilan kebijakan saham bonus dalam suatu perusahaan, maka hal tersebut tidak memengaruhi nilai pasar saham` perusahaan emiten bersangkutan. Hasil penelitian ini tidak mampu mendukung teori keagenan dan teori sinyal yaitu bahwa pengumuman saham bonus yang dipublikasikan tidak memberikan sinyal apapun bagi investor di pasar saham.

Kebijakan saham bonus yang dilakukan perusahaan dinilai tidak memberikan penambahan kekayaan bagi investor karena perusahaan tidak mengeluarkan biaya dalam bentuk dividen tunai, melainkan hanya dalam bentuk dividen saham. Pembagian dividen secara tunai lebih mampu menarik perhatian investor dibandingkan dengan dividen dengan proporsi kepemilikan saham, 
sehingga pembagian saham bonus tidak mengakibatkan respon dari pasar. Hasil penelitian ini di dukung oleh penelitian Ardiansyah (2013), Dewi dan Sukartha (2015), Sundari dkk. (2014) dalam Larasdiputra dkk. (2017), Mahfudatin dan Maslichah (2018) yang menemukan bahwa tidak ada pengaruh antara saham bonus terhadap nilai perusahaan.

Implikasi teoritis penelitian ini dapat memberikan kontribusi mengenai pengaruh rentabilitas, leverage, dan saham bonus pada nilai perusahaan. Berdasarkan hasil uji dalam penelitian ini dapat diketahui bahwa rentabilitas berpengaruh negatif pada nilai perusahaan. Hasil penelitian ini mendukung teori keagenan dan teori sinyal yang menyatakan bahwa manajer dapat melakukan kebijakan untuk mencapai tujuan yang diinginkannya, seperti meningkatkan tingkat suku bunga untuk meningkatkan rentabilitas, namun hal ini ternyata memberikan sinyal negatif ( $b a d$ news) sehingga nilai perusahaan menurun. Hasil uji dalam penelitian ini menyebutkan bahwa leverage berpengaruh positif signifikan pada nilai perusahaan, dimana hasil tersebut sesuai dengan teori sinyal dan teori keagenan yang menyebutkan bahwa manajer sebagai pengelola dapat melakukan kebijakan utang untuk meningkatkan nilai perusahaan di mata investor. Hasil uji penelitian ini juga menyatakan bahwa saham bonus tidak berpengaruh pada nilai perusahaan, dimana hal ini membuktikan tinggi rendahnya intensitas pengambilan kebijakan saham bonus oleh manajer untuk dipublikasikan tidak akan memengaruhi nilai perusahaan dikarenakan investor tidak merespon saham bonus sebagai sinyal. 
Implikasi praktis penelitian ini dapat dipergunakan oleh semua pihak yang berkepentingan di dunia pasar modal, khususnya bagi investor dan perusahaan. Penelitian selanjutnya diharapkan dapat mempertimbangkan variabel dan proksi lain seperti ukuran perusahaan, struktur modal, ROA, dividen saham, dan sebagainya yang diduga berpengaruh pada nilai perusahaan. Implikasi bagi investor yaitu sebagai dasar pertimbangan agar dapat lebih berhati-hati dalam pengambilan keputusan investasi terkait kebijakan yang dikeluarkan perusahaan. Bagi perusahaan, penelitian ini dapat digunakan sebagai bahan pertimbangan dalam pengambilan keputusan maupun kebijakan yang nantinya dilakukan karena keputusan yang diambil akan memengaruhi kelangsungan hidup perusahaan dan preferensi investor terhadap prospek perusahaan.

\section{SIMPULAN}

Simpulan yang dapat diberikan berdasarkan hasil analisis data dan pembahasan yang telah diuraikan yaitu pertama, variabel rentabilitas berpengaruh negatif signifikan pada nilai perusahaan. Kedua, variabel leverage berpengaruh positif signifikan pada nilai perusahaan. Ketiga, variabel saham bonus tidak berpengaruh pada nilai perusahaan.

Saran-saran yang dapat diberikan berkaitan dengan hasil penelitian serta untuk kesempurnaan penelitian selanjutnya yaitu perusahaan diharapkan lebih menimbang keputusan dalam pengambilan keputusan kebijakan perusahaan dengan memperhatikan prospek perusahaan dan implikasi yang ditimbulkan dengan adanya informasi yang dipublikasikan emiten. Kemudian, bagi investor 
diharapkan mampu menganalisa laporan keuangan tahunan dan informasi terkait lainnya yang dipublikasikan di Bursa Efek Indonesia terkait kebijakan perusahaan agar dapat mengambil keputusan secara tepat dalam berinvestasi. Bagi peneliti selanjutnya diharapkan mampu menggunakan variabel serta proksi lain seperti ukuran perusahaan, struktur modal, ROA, dividen saham, dan sebagainya yang lebih dapat memengaruhi nilai perusahaan.

\section{REFERENSI}

Adelegan, O. (2006). Effects of Taxes Financing Decisions and Firm Value in Nigeria. Proceedings of the German Development Economics Conference. Berlin.

Agustina \& Silvia. (2012). Pengaruh Rasio Keuangan Terhadap Perubahan Laba Pada Perusahaan Manufaktur Yang Terdaftar Di Bursa Efek Indonesia. Jurnal Wira Ekonomi Mikroskil, 1(2), 113-122.

Analisa, Y. (2011). Pengaruh Ukuran Perusahaan, Leverage, Profitabilitas dan Kebijakan Dividen terhadap Nilai Perusahaan. Skripsi. Universitas Diponegoro Semarang.

Ardiansyah, F. (2013). Analisis Reaksi Pengumuman Saham Bonus Terhadap Return Dan Abnormal Return Di Bursa Efek Indonesia 2000-2012. Jurnal Ilmiah Mahasiswa FEB, 1(2), 1-15.

Barnes, M. L., \& Ma, S. (2002). The Behavior of China's Stock Prices in Response to the Proposal and Approval of Bonus Issues.

Brigham, Eugine, \& Philip R. Daves. (2000). Intermediate Finnancial Management (Tenth Edition). South Western: Cengage Learning.

Carningsih. (2009). Pengaruh Good Corporate Governance Terhadap Hubungan Antara Kinerja Keuangan Dengan Nilai Perusahaan (Studi Kasus Pada Perusahaan Property dan Real Estate yang Terdaftar Di Bursa Efek Indonesia). Jurnal Akuntansi Dan Keuangan, 21, 1-8. 
Chen, L.-J., \& Chen, S.-Y. (2011). The Influence of Profitability on Firm Value With Capital Structure as The Mediator and Firm Size and Industry as Moderators. Incestment Management and Financial Innovations Journal, $8(3), 121-129$.

Cheng, M.-C., \& Tzeng, Z.-C. (2011). The Effect of Leverage on Firm Market Value and How Ther Firm Financial Quality Influence on This Effect. World Journal of Management, 3(2), 30-53.

Chung, K. H., \& Pruitt, S. W. (1994). A Simple Approximation of Tobin's Q. Journal Financial Management, 23(3), 70-74.

Dewi, A. S. M., \& Wirajaya, A. (2013). Pengaruh Struktur Modal, Profitabilitas dan Ukuran Perusahaan pada Nilai Perusahaan. E-Jurnal Akuntansi Universitas Udayana, 4(2), 358-372.

Dewi, N. P. D. R., \& Sukartha, I. M. (2015). Reaksi Pasar Terhadap Pengumuman Saham Bonus di Bursa Efek Indonesia. E-Jurnal Akuntansi Universitas Udayana, 10(1), 150-163.

Dimitrov, V., \& Jain, P. C. (2008). The Value - Relevance of Changes in Financial Leverage Beyond Growth in Assets and GAAP Earnings. Journal of Accounting, 23(2), 191-222.

Dirgantara, K.A., \& Lubis, A.W. (2013). Pengaruh Perubahan Tingkat Utang Terhadap Tingkat Pengembalian Saham, Investasi, dan Kinerja Masa Depan Perusahaan Yang Tercatat Di Bursa Efek Indonesia 2007-2011. Artikel Ilmiah. Universitas Indonesia.

Gill, A., \& Obradovich, J. (2012). The Impact of Corporate Governance and Financial Leverage on the Value of American Firms. International Research Journal of Finance and Economics, (91), 1-14.

Hasibuan, V., Dzulkirom AR, M., \& Endang NP, N. G. W. (2016). Pengaruh Leverage dan Profitabilitas Terhadap Nilai Perusahaan (Studi pada Perusahaan Property dan Real Estate yang Terdaftar di Bursa Efek Indonesia Periode Tahun 2012-2015). Jurnal Administrasi Bisnis (JAB), 39(1), 139-147. 
Hermawan, S., \& Maf'ulah, A. N. (2014). Pengaruh Kinerja Keuangan Terhadap Nilai Perusahaan dengan Pengungkapan Corporate Social Responsibility Sebagai Variabel Pemoderasi. Jurnal Dinamika Akuntansi, 6(2), 103-118.

Herry, \& Hamin. (2005). Tingkat Kepemilikan Manajerial dan Nilai Perusahaan: Bukti Empiris pada Perusahaan Publik di Indonesia. Simposium Riset Ekonomi II. Surabaya.

Khumairoh, Kalbuana, N., \& Mulyati, H. (2016). Pengaruh Leverage, Profitabilitas, dan Ukuran Perusahaan Terhadap Nilai Perusahaan. Syariah Paper Accounting FEB UMS, 71-81.

Lakonishok, J., \& Lev, B. (1987). Stock Splits and Stock Dividends: Why, Who, and When. The Journal of Finance, 42(4), 913-932.

Larasdiputra, D., Yadnyana, I. K., \& Astika, I. B. P. (2017). Pengaruh Rentabilitas dan Leverage pada Keputusan Saham Bonus dan Implikasinya pada Nilai Perusahaan. E-Jurnal Ekonomi Dan Bisnis Universtias Udayana, 6(4), 1575-1608.

Lestari, S. A. (2016). Pengaruh Profitabilitas terhadap Nilai Perusahaan pada Perusahaan Manufaktur yang terdaftar di Bursa Efek Indonesia Periode 2009-2014. Skripsi. Universitas Hasanuddin.

Lyandres, E., \& Zhdanov, A. (2010). Accelerated Investment Effect of Risky Debt. Journal of Banking and Finance, 34(11), 2587-2599.

Mahfudatin, \& Maslichah, H. (2018). Pengaruh Rentabilitas dan Leverage Terhadap Nilai Perusahaan dengan Keputusan Saham Bonus Sebagai Variabel Intervening. Jurnal Riset Akuntansi, 7(2), 118-130.

Menawati, N. M. W., \& Astika, I. B. P. (2017). Pengaruh Rentabilitas dan Likuiditas pada Jumlah Opsi Saham dan Dampaknya pada Nilai Perusahaan. E-Jurnal Akuntansi Universitas Udayana, 18(3), 1915-1942.

Miftah, A. (2008). Analisis Faktor-Faktor yang Mempengaruhi Kebijakan Utang pada Perusahaan Manufaktur di Bursa Efek Indonesia. Skripsi. Universitas Muhammadiyah Surakarta. 
Munawaroh. (2013). Pengaruh Ukuran Perusahaan, Leverage, dan Profitabilitas Terhadap Nilai Perusahaan pada Perusahaan-Perusahaan LQ-45. Artikel Ilmiah. STIE Perbanas Surabaya.

Myers, S. C. (1977). Determinants of Corporate Borrowing. Journal of Financial Economics, 5, 147-175.

Prasetyorini, B. F. (2013). Pengaruh Ukuran Perusahaan, Leverage, Price Earning Ratio dan Profitabilitas Terhadap Nilai Perusahaan. Jurnal Ilmu Manajemen, 1(1), 183-196.

Pratama, I. G. B. A., \& Wiksuana, I. G. B. (2016). Pengaruh Ukuran Perusahaan dan Leverage Terhadap Nilai Perusahaan dengan Profitabilitas Sebagai Variabel Mediasi. E Jurnal Manajemen Unud, 5(2), 1338-1367.

Sally, I. (2015). Pengaruh Good Corporate Governance terhadap Hubungan Profitabilitas dan Manajemen Laba dengan Nilai Perusahaan. Artikel Ilmiah. Universitas Negeri Padang.

Shirur, S. (2008). Dilemma of Corporate Action: Empirical Evidences of Bonus Issue vs. Stock Split. Journal Vikalpa, 33(3), 35-47.

Siahaan, F. O. P. (2013). The Effect of Good Corporate Governance Mechanism, Leverage and Firm Size on Firm Value. GSTF Journal on Business Review, 2(4), 137-142.

Samsul, Mohamad. (2006). Pasar Modal dan Manajemen Portofolio. Jakarta: Erlangga.

Sugiyono. (2017). Metode Penelitian Kuantitatif, Kualitatif, dan R\&D. Bandung: Alfabeta

Suharli, M. (2006). Studi Empiris Mengenai Pengaruh Profitabilitas, Leverage, dan Harga Saham Terhadap Jumlah Dividen Tunai. Jurnal Maksi, 6(2), 243-256.

Tarihoran, A. (2016). Pengaruh Penghindaran Pajak dan Leverage Terhadap Nilai Perusahaan dengan Transparansi Perusahaan sebagai Variabel Moderasi. Jurnal Wira Ekonomi Mikroskil, 6(2), 149-164. 
Ni Wayan Yusy Marthadiani dan Ida Bagus Putra Astika. Pengaruh ...

Titman, S., \& Wessels, R. (1988). The Determinants of Capital Structure Choice. Journal of Finance, 43(1), 1-19.

Triagustina, L., Sukarmanto, E., \& Helliana. (2015). Pengaruh Return on Asset (ROA) dan Return on Equity (ROE) Terhadap Nilai Perusahaan pada Perusahaan Manufaktur Subsektor Makanan dan Minuman yang Terdaftar di Bursa Efek Indonesia Periode 2010-2012. Jurnal Prosiding Akuntansi.

Wiagustini. (2014). Dasar-dasar Manajemen Keuangan. Denpasar: Udayana University Press.

Wulandari, N. M. I., \& Wiksuana, I. G. B. (2017). Peranan Corporate Social Responsibility Dalam Memoderasi Pengaruh Profitabilitas, Leverage dan Ukuran Perusahaan Terhadap Nilai Perusahaan. E-Jurnal Manajemen Unud, 6(3), 1278-1311. 